\title{
KEMAMPUAN PEMECAHAN MASALAH MATEMATIS MODEL PEMBELAJARAN INQUIRI TERBIMBING DAN MEANS ENDS ANALYSIS
}

\author{
Yenny Puspita Sari ${ }^{1}$, Masri ${ }^{2}$ \\ 1,2Program Studi Pendidikan Matematika FKIP Universitas Muhammadiyah Bengkulu \\ yenny@gmail.com ${ }^{1}$, masritan@gmail.com ${ }^{2}$
}

\begin{abstract}
In this research aims to see the difference of mathematical problem solving students with Guided Inquiry learning model and Means Ends Analysis (MEA) learning model. This research was a quasi-experimental research in SMPN 14 Kota Bengkulu. The population of this research is all of VIII class students, with the sample of research is VIII I class as the experimental class I that given using guided inquiry model treatment, students of class VIII 3 as the experimental class II that given Means Ends Analysis model treatment, students of class VIII 2 as the control class that given conventional model treatment. The data collection of students result study using mathematical problem solving skills test consists of pre-test and post-test. The data obtained were analyzed using one path ANAVA and continued with BNT test. Based on the ANAVA result there is a difference between students' mathematical problem solving abilities in experimental class I, experimental class II and control class. From the BNT test that the treatment between experimental class I given the Guided Inquiry, Experimental class II treatment given the Means Ends Analysis treatment no difference in mathematical problem solving ability, while experimental class I (Guided Inquiry) with control and experimental class II Means Ends Analysis with the control there is a difference in problem solving abilities mathematically and the highest average score was obtained in the students treated with the Guided Inquiry model. Keywords : Ability of Mathematical Problem Solving Students, Guided Inquiry Model, Means Ends Analysis Model
\end{abstract}

\section{PENDAHULUAN}

Pembelajaran merupakan istilah yang digunakan untuk menunjukan kegiatan guru dan siswa atau pengelolahan sumber dan prosedur yang dapat meningkatkan belajar siswa. Menurut Majid (2016:5) "pembelajaran adalah suatu konsep dari dua dimensi kegiatan (belajar dan mengajar) yang harus direncanakan dan diaktualisasikan, serta diarahkan pada pencapaian tujuan atau penguasaan sejumlah kompetensi dan indikatornya sebagai hasil belajar".

Kemampuan pemecahan masalah merupakan bagian penting dalam kurikulum matematika, karena proses pembelajaran maupun penyelesaian siswa memungkinkan untuk dapat memperolehpengetahuan serta menggunakan pengetahuan yang sudah dimiliki untuk pemecahan masalah.Salah satu tujuan pembelajaran dalam
Permendiknas No. 22 Tahun 2006 tentang standar isi (BSNP, 2006:140) yaitu "agar siswa memiliki kemampuan memecahkan masalah yang meliputi kemampuan memahami masalah, merancang model matematika, menyelesaikan model dan menafsirkan solusi yang diperoleh". Menurut Sumarmo (2012) bahwa "kemampuan pemecahan masalah merupakan jantungnya matematika". Selanjutnya Ruseffendi (2012:3) mengemukakan bahwa " kemampuan pemecahan masalah penting dalam matematika, bukan saja bagi merekan yang akan mendalami atau mempelajari matematika, melainkan juga bagi mereka yang akan menerapkannya dalam bidang studi lain dan dalam kehidupan seharihari”. Kemampuan pemecahan masalah matematis siswa dapat dilihat dari indikator penyelesaian yaitu: memahami masalah, merencanakan penyelesaian, menyelesaikan 
masalah sesuai rencana dan melakukan pengecekan kembali terhadap semua langkah yang telah dikerjakan.

Model pembelajaran yang dianggap cocok untuk menumbuh kembangkan kemampuan pemecahan masalah matematis diantaranya model Inquiri Terbimbingdan modelMeans Ends Analysis (MEA).Model pembelajaran inquiri terbimbing merupakanmodel pembelajaran inquiri yang lebih terstruktur, dimana guru mengendalikan keseluruhan proses interaksi dan menjelaskan prosedur penelitian yang harus dilakukan oleh siswa.Menurut Afandi(2013:4) "langkah- langkah dalam pembelajaran inquiri terbimbing dimulai dari merumuskan masalah, mengajukan hipotesis, mengumpulkan bukti atau data, menarik kesimpulan". Model pembelajaran inquiri terbimbing merupakan model pembelajaran yang diorganisasikan lebih terstruktur, dimana guru mengendalikan keseluruhan proses interaksi dan menjelaskan prosedur penelitian yang harus dilakukan oleh siswa. Dalam model ini, guru diharapkan mampu mendorong siswa untuk bagaimana siswa memahami masalah, berpikir memberikan suatu dugaan sementara dari suatu gejala atau situasi, kemudian mengumpulkan data, melakukan pengamatan dan penyelidikan untuk memberikan jawaban atas dugaan yang telah dirumuskan.Sedangkan model pembelajaran MeansEnds Analysis (MEA) adalah suatu model pembelajaran yang merupakan variasi pemecahan masalah dengan bermacam cara sehingga mendapatkan hasil atau tujuan akhir. Siswa tidak hanya dinilai berdasarkan hasilnya saja, namun berdasarkan proses pengerjaannya. Selain itu siswa dituntut mengetahui apa tujuan yang hendak dicapai atau masalah apa yang hendak diselesaikan. Siswa diharuskan memecahkan suatu masalah kedalam dua atau lebih sub tujuan dan kemudian dikerjakan berturut-turut pada masing-masing sub tujuan.Model ini lebih memusatkan pada perbedaan antara pernyataan sekarang dengan tujuan yang hendak dicapai. Hal ini sesuai dengan pendapat Yulita (2015) bahwa "model pembelajaran Means Ends Analysis (MEA)adalah suatu model pembelajaran yang merupakan variasi antara metode pemecahan masalah dengan bermacam cara sehingga mendapatkan hasil atau tujuan akhir". Model pembelajaran Means Ends Analysis (MEA)menurut Suherman (2008) adalah "merupakan model pembelajaran yang menyajikan materi dengan pendekatan pemecahan masalah berbasis heuristik".Pada model pembelajaran Means Ends Analysis (MEA), siswa siswa akan diajarkan cara memecahkan sebuah masalah menjadi beberapa sub masalah, sehingga siswa akan lebih mudah memandang suatu masalah lalu menyelesaikannya dan siswa yang dominan berperan dalam proses pembelajaran, sedangkan guru berperan sebagai fasilitator dan motivator.

Menurut Buto (Novitasari, 2017) Pembelajaran konvensional adalah proses pembelajar yang biasa dilakukan disekolah dengan pola guru menjelaskan materi dan tanya jawab, memberikan contoh soal dan non contoh soal beserta cara menyelesaikannya, diakhiri dengan memberikan latihan soal kepada siswa.Model pembelajaran konvensional merupakan model pembelajaran yang lebih berpusat pada guru dan lebih mengutamakan strategi pembelaajaran efektif guna memperluas informasi materi ajar.

Adapun indikator untuk mengetahui kemampuan pemecahan masalah matematis siswa menurut Suherman (Windari, 2014) :

1. Memahami masalah (siswa dapat mengidentifikasi unsur-unsur yang diketahui, yang ditanyakan, dan kecukupan unsur yang diperlukan).

2. Merencanakan masalah (siswa dapat merumuskan masalah matematika atau menyusun model matematika dan juga siswa dapat menerapkan strategi untuk menyelesaikan berbagai masalah).

3. Menyelesaikan masalah (siswa diharapkan mampu melakukan penyelesaian pelaksanaan dengan baik).

4. Melakukan pengecekan kembali dan mengambil kesimpulan.

Indikator kemampuan pemecahan masalah menurut Sumarmo (2007) adalah: 
1. Mengidentifikasi kecukupan data untuk pemecahan masalah.

2. Membuat model matematika dari suatu situasi atau masalah sehari-hari dan menyelesaikannya.

3. Menerapkan strategi untuk menyelesaikan masalah matematika didalam atau diluar matematika.

4. Menjelaskan atau menginterpretasikan hasil yang sesuai permasalahan asal, serta memeriksa kebenaran hasil atau jawaban.

5. Menerapkan matematika secara bermakna.

\section{METODE}

Jenis penelitian ini adalah penelitian eksperimen semu (quasi eksperimental). Penelitian ini akan dilaksanakan di SMPN 14 Kota Bengkulu pada bulan April semester genap tahun ajaran 2017/2018. Populasi dalam penelitian ini adalah seluruh siswa kelas VIII SMPN 14 Kota Bengkulu yang terdiri dari 8 kelas.Sampel pada penelitian ini terdiri 3 kelas yaitu kelas $\mathrm{VIII}_{1}$ sebagai kelas eksperimen I (Inquiri Terbimbing), kelas $\mathrm{VIII}_{3}$ sebagai kelas eksperimen II (Means Ends Analysis) dan kelas $\mathrm{VIII}_{2}$ sebagai kelas kontrol dari 8 kelas populasi.Sampling dalam penelitian ini menggunakan teknik sampel acak sederhana (simple random sampling) dengan mengacak kelas dari populasi.Metode pengumpulan data penelitian ini adalah tes, tes yang digunakan berupa soal uraian. Instrumen dalam penelitian ini adalah lembar tes, lembar tes terdiri dari pre-test dan post-test. Prosedur dalam penelitian terdiri dari tahap persiapan, tahap pelaksanaan dan tahap analisis data, pada tahap analisis data, seluruh data yang diperoleh dari pre-test maupun post-testdianalisis secara statistik.Uji statistic yang digunakan adalah uji Normalitas, uji Homogenitas dan uji Analisis Varians (Anava).

\section{HASIL PENELITIAN DAN PEMBAHASAN}

Data hasil skor post-test kemampuan pemecahan masalah matematis siswa kelas eksperimen I (Inquiri Terbimbing), eksperimen II (Means Ends Analysis) dan kelas Kontrol dapat dilihat pada tabel 1 berikut ini.

Tabel 1. Hasil SkorPost-test Kemampuan Pemecahan Masalah Matematis

\begin{tabular}{|c|c|c|c|}
\hline \multirow{2}{*}{ Data } & \multicolumn{3}{|c|}{ Kelas } \\
\cline { 2 - 4 } & Experimen I & Experimen II & Kontrol \\
\hline Skor Total & 735 & 690 & 648 \\
\hline Skor Tertinggi & 33 & 30 & 28 \\
\hline Skor Terendah & 18 & 18 & 16 \\
\hline Rata-rata Skor & 25,4 & 23,4 & 21,1 \\
\hline Simpangan Baku & 4,869 & 3,785 & 3,832 \\
\hline Varians & 23,703 & 14,324 & 14,686 \\
\hline
\end{tabular}

Uji normalitas data diperlukan untuk menguji apakah data berdistribusi normal atau tidak.Pengujian normalitas data dilakukan dengan menggunakan uji
kolmogrov-smirnov.Hasil perhitungan uji Kolmogorov-Smirnov dapat dilihat pada tabel 2 berikut :

Tabel 2. Ringkasan Uji Kolmogrov-SmirnovPost-test

\begin{tabular}{|c|c|c|c|c|c|}
\hline Kelas sampel & $\begin{array}{c}\text { Jumlah } \\
\text { Sampel }\end{array}$ & $\mathrm{a}_{\text {hitung }}$ & $\mathrm{a}_{\text {tabel }}$ & Kriteria & Keputusan \\
\hline Eksperimen I & 30 & 0,1665 & 0,242 & $\mathrm{a}_{\text {hitung } \prec \mathrm{a}_{\text {tabel }}}$ & Terima $\mathrm{H}_{0}$ \\
\hline Eksperimen II & 30 & 0,1443 & 0,242 & $\mathrm{a}_{\text {hitung }} \mathrm{a}_{\text {tabel }}$ & Terima $\mathrm{H}_{0}$ \\
\hline Kontrol & 30 & 0,1577 & 0,242 & $\mathrm{a}_{\text {hitung } \prec \mathrm{a}_{\text {tabel }}}$ & Terima $\mathrm{H}_{0}$ \\
\hline
\end{tabular}


Dari tabel 2.uji Kolmogrov-Smirnov diatas dapat dilihat bahwa untuk semua kelas sampel, baik pada kelas eksperimen maupun kelas kontrol, nilai $\mathrm{a}_{\text {hitung }}<\mathrm{a}_{\text {tabel }}$ maka terima $\mathrm{H}_{0}$. Dengan demikian disimpulkan bahwa data post-test pada kelas inquiri terbimbing, Mean Ends Analysis dan konvensional memiliki sebaran data yang menyebar normal.
Uji homogenitas varians diperlukan untuk menguji apakah varians dari ketiga kelas tersebut homogen atau tidak.Pengujian homogenitas varians dilakukan dengan menggunakan uji bartlett. Hasil uji homogenitas varians dapat dilihat pada tabel 3 berikut :

Tabel 3. Uji Homogenitas Bartlett Post-test

\begin{tabular}{|l|c|c|c|c|c|}
\hline \multicolumn{1}{|c|}{ Sampel } & $\mathrm{Dk}$ & $\mathrm{Si}^{\wedge} 2$ & $\log \mathrm{Si}^{\wedge} 2$ & $\mathrm{dk} \cdot \mathrm{Si}^{\wedge} 2$ & \multicolumn{1}{c|}{$\mathrm{dk} \cdot \log \mathrm{S}^{\wedge} 2$} \\
\hline Inquiri Terbimbing & 29 & 23,703 & 1,375 & 687,387 & 39,8693 \\
\hline Means Ends Analysis & 29 & 14,324 & 1,156 & 415,396 & 33,5259 \\
\hline Konvensional & 29 & 14,686 & 1,167 & 425,894 & 33,8402 \\
\hline Jumlah & 87 & 52,713 & & 1528,677 & 107,2354 \\
\hline
\end{tabular}

Dari perhitungan uji homogenitas tabel 3 diatas, diperoleh bahwa nilai $x^{2}{ }_{\mathrm{h}}<x^{2}{ }_{\mathrm{t}(\alpha ; \mathrm{n})}$ maka terima $\mathrm{H}_{0}$. Dengan demikian disimpulkan bahwa data post-test kelas eksperimen I, kelas eksperimen II dan kelas kontrol mempunyai varians homogen.
Jika data berdistribusi normal dan varians homogen, maka dilanjutkan dengan uji ANAVA untuk menguji apakah ada perbedaan yang signifikan kemampuan pemecahan masalah matematis antara tiga kelas sampel tersebut.

Tabel 4. Uji Analisis Varians (ANAVA) Post-test

\begin{tabular}{|c|c|c|c|c|c|}
\hline $\begin{array}{l}\text { Sumber } \\
\text { Varians }\end{array}$ & $\mathrm{db}$ & $\begin{array}{l}\text { Jumlah } \\
\text { Kuadrat }\end{array}$ & $\begin{array}{c}\text { Kuadrat } \\
\text { Tengah }\end{array}$ & $F_{\text {hitung }}$ & $\mathrm{F}_{\text {tabel }}$ \\
\hline Total & 89 & 1815,3 & - & \multirow{3}{*}{8,158} & \multirow{3}{*}{3,10} \\
\hline $\begin{array}{c}\text { Antar } \\
\text { Kelompok }\end{array}$ & 2 & 286,689 & 143,344 & & \\
\hline $\begin{array}{c}\text { Antar } \\
\text { Kelompok }\end{array}$ & 87 & 1528,6 & 17,570 & & \\
\hline
\end{tabular}

Berdasarkan hasil analisis Varians posttest (tabel 4) diperoleh $\mathrm{F}_{\mathrm{h}}>\mathrm{F}_{\mathrm{t}}$ yaitu8,158 $>3,10$ maka tolak $\mathrm{H}_{0}$, disimpulkan bahwa ada perbedaan signifikan kemampuan pemecahan masalah matematis siswa setelah diberikan perlakuan model pembelajaran inquiri terbimbing,model pembelajaran Means
Ends Analysis, dan model Konvensional.Dengan demikian sedikitnya ada sepasang perlakuan yang memberikan hasil kemampuan pemecahan masalah matematis siswa yang berbeda. Hal ini dapat dilihat dari uji BNT (beda nyata terkecil) pada tabel 5 berikut: 
Tabel 5. Hasil Uji Beda Nyata Terkecil (BNT) Post-test

\begin{tabular}{ccccc}
\hline $\begin{array}{c}\text { Selisih Rata-Rata } \\
\text { Antar Perlakuan }\end{array}$ & $\bar{X}_{\iota}-\bar{X}_{J}$ & $\begin{array}{c}\text { BNT } \\
(\alpha=0,05)\end{array}$ & Kategori & Kesimpulan \\
\hline$\left|\overline{X_{1}}-\overline{X_{2}}\right|$ & 2 & 2,15 & $\left|\overline{X_{1}}-\overline{X_{2}}\right|<$ BNT & Terima $H_{0}$ \\
\hline$\left|\overline{X_{1}}-\overline{X_{3}}\right|$ & 4,3 & 2,15 & $\left|\overline{X_{1}}-\overline{X_{3}}\right|>$ BNT & Tolak $H_{0}$ \\
\hline$\left|\overline{X_{2}}-\overline{X_{3}}\right|$ & 2,3 & 2,15 & $\left|\overline{X_{2}}-\overline{X_{3}}\right|>$ BNT & Tolak $H_{0}$
\end{tabular}

Kriteria pengujian : $\left|\bar{X}_{l}-\bar{X}_{J}\right|>B N T$, maka tolak $\mathrm{H}_{0}$.

Berdasarkan hasil uji Beda Nyata Terkecil (BNT) pada tabel 5, diperoleh $\left|\overline{X_{1}}-\overline{X_{2}}\right|<B N T$ yakni $2<2,15$, maka terima $\mathrm{H}_{0}$, disimpulkan tidak ada perbedaan kemampuan pemecahan masalah matematis antara model pembelajaran Inquiri Terbimbing dan Model Mean Ends Analysis(MEA).Selanjutnya Karena $\mid \overline{X_{1}}-$ $\overline{X_{3}} \mid>B N T$ yakni 4,3> 2,15 maka tolak $\mathrm{H}_{0}$, disimpulkan ada perbedaan kemampuan pemecahan masalah matematis antara model Pembelajaran Inquiri Terbimbing dan pembelajaran Konvensional. Kemudian karena $\left|\overline{X_{2}}-\overline{X_{3}}\right|>B N T$ yakni $2,3>2,15$ maka tolak $\mathrm{H}_{0}$,disimpulkan ada perbedaan kemampuan pemecahan masalah matematis antara pembeajaran Model Mean Ends Analysis (MEA) dan Pembelajaran Konvensional.

\section{SIMPULAN}

Kesimpulan dari penelitian ini adalah:

1. Ada perbedaan kemampuan pemecahan masalah matematis siswa yang diajarkan dengan model pembelajaran Inquiri Terbimbing, model pembelajaran Means Ends Analysis(MEA)dan model pembelajaran konvensional di kelas VIII SMPN 14 Kota Bengkulu.

2. Model pembelajaran Inquiri Terbimbingdan model pembelajaran Means Ends Analysis (MEA) memberikan hasil kemampuan pemecahan masalah matematis siswa yang lebih baik dibandingkan model konvensional. Berdasarkan skor rata-rata post-test model pembelajaran Inquiri Terbimbing memperolehhasilkemampuan pemecahan masalah matematis yang lebih baik dibandingkan model pembelajaran Means Ends Analysis (MEA) dan pembelajaran Konvensional.

\section{REFERENSI}

Afandi, A dan Wustqa, U.D. 2013.Pendekatan Open-ended dan Inkuiri Terbimbing ditinjau dari Kemampuan Pemecahan Masalah dan Representasi Multipel Matematis.Jurnal Pendidikan Matematika. Volume 8 Nomor 1, Juni 2013, (1-11). http://journal.uny.ac.id/index.php/pythag oras

BSNP.2006. Standar Isi untuk Satuan Tingkat Pendidikan Dasar dan Menengah.BSNP. Jakarta.

Majid, A. 2016.Strategi Pembelajaran. PT. Remaja Rosdakarya. Bandung.

Novitasari. 2017. Kemampuan Pemecahan Masalah Matematis Siswa dengan Model Discovery Learning dan Model Inquiri Pada Siswa KelasVIII SMP. Skripsi. Universitas Muhammadiyah Bengkulu.

Suherman, E. 2008. Model Belajar dan Pembelajaran Berorientasi Kompetensi Siswa. EDUCARE Jurnal Pendidikan dan Budaya. Vol.5.No.2. hal1-31.

Sumarmo, U. 2007. Pembelajaran Matematika. Rujukan Filsafat, Teori, dan Praktis Ilmu Pendidikan. UPI Press. Bandung.

Sumarmo, U. 2012. Proses Berpikir Matematik.Apa dan Mengapa Dikembangkan. UPI Press. Bandung.

Windari, F. , Dwina, F. , dan Suherman. 2014. Meningkatkan Kemampuan Pemecahan Masalah Matematika Siswa Kelas VIII SMPN 8 Padang Tahun Pelajaran 2013/2014 Dengan Menggunakan Strategi Pembelajaran 
Jurnal MATH-UMB.EDU

Vol 7 (2), Tahun 2020

Inkuiri. Jurnal Pendidikan Matematika 3(2): 25-28.

Yulita, F. 2015. Kemampuan Siswa Memecahkan Masalah Melalui Strategi Means Ends Analysis Pada Materi Differensial di Kelas XI IPA MAN Model Banda Aceh. Jurnal Peluang, Volume

4. http://www.jurnal.unsyiah.ac.id/pelua ng/article/view/5852 